\title{
Seismic and Power Generation Performance of U-Shaped Steel Connected PV-Shear Wall under Lateral Cyclic Loading
}

\author{
Hongmei Zhang, ${ }^{1}$ Jinzhi Dong, ${ }^{1}$ Yuanfeng Duan, ${ }^{2}$ Xilin Lu, ${ }^{1}$ and Jinqing Peng ${ }^{3}$ \\ ${ }^{1}$ State Key Laboratory of Disaster Reduction in Civil Engineering, Tongji University, Shanghai 200092, China \\ ${ }^{2}$ College of Civil Engineering and Architecture, Zhejiang University, Hangzhou 310058, China \\ ${ }^{3}$ Renewable Energy Research Group, Department of Building Services Engineering, \\ The Hong Kong Polytechnic University, Hong Kong \\ Correspondence should be addressed to Yuanfeng Duan; ceyfduan@zju.edu.cn
}

Received 2 May 2014; Accepted 12 May 2014; Published 6 August 2014

Academic Editor: Hui Shen

Copyright (C) 2014 Hongmei Zhang et al. This is an open access article distributed under the Creative Commons Attribution License, which permits unrestricted use, distribution, and reproduction in any medium, provided the original work is properly cited.

BIPV is now widely used in office and residential buildings, but its seismic performance still remained vague especially when the photovoltaic (PV) modules are installed on high-rise building facades. A new form of reinforced concrete shear wall integrated with photovoltaic module is proposed in this paper, aiming to apply PV module to the facades of high-rise buildings. In this new form, the PV module is integrated with the reinforced concrete wall by U-shaped steel connectors through embedded steel plates. The lateral cyclic loading test is executed to investigate the seismic behavior and the electric and thermal performance with different drift angles. The seismic behavior, including failure pattern, lateral force-top displacement relationship, and deformation capacity, was investigated. The power generation and temperature variation on the back of the PV module and both sides of the shear wall were also tested. Two main results are demonstrated through the experiment: (1) the U-shaped steel connectors provide enough deformation capacity for the compatibility of the PV module to the shear wall during the whole cyclic test; (2) the electricity generation capacity is effective and stable during this seismic simulation test.

\section{Introduction}

Solar energy is clean and renewable energy. At present, using solar energy to generate electricity has been concerned by a growing number of researchers. According to the report of International Energy Agency, there will be onefifth of the whole global energy produced by solar system by 2050 and a rise of $60 \%$ is anticipated by the end of this century [1]. Since buildings consume more than $30 \%$ energy in the world, the building-integrated photovoltaic (BIPV) technology which integrates photovoltaic (PV) modules with building envelopes, such as roofs, vertical facades, or windows, becomes a popular application form $[2,3]$. One of the most attractive characteristics of BIPV is the conversion of the buildings from an energy consumer with a proportion of $30 \% \sim 60 \%$ to an energy producer by themselves without occupying land [4-6]. Moreover, PV integrated buildings offer considerable scope for energy-demand offsets and reduction of greenhouse (GHG) emissions and achieve local use of electricity to avoid transmission and distribution investments and the associated losses [7]. In the latest 5 years, BIPV becomes one of the fastest growing segments of the solar industry all over the world with a predicted capacity growth of over 50\% from 2011 to 2017 [8].

For the envelope of high-rise buildings, the area of facades is much larger than that of roofs, although the angle of inclination is not the best one in terms of power generation when integrating PV modules on these buildings. According to related studies, the unit power generation capacity of the PV modules on building facades is also considerable comparing with that of roofs $[9,10]$. And the total power generation value of the PV on building facades is far more than that of roofs. According to current studies, the facade photovoltaic systems can be classified into three basic types including facadesintegrated cladding, curtain walls, and structural glazing [7], and the integration manners, materials, characteristics, and typical cases for each type of system were investigated. Han et al. [11] evaluated the outdoor performance of a naturally 
ventilate double-sided PV facade through field monitoring from a small scale test rig. Research results indicated that the heat gain from facade in summer could be substantially reduced and additional electrical power can also be generated from such facade as a byproduct. Yang et al. conducted an experiment to evaluate the cooling load component contributed by building-integrated PV walls and showed that the PV wall can reduce the corresponding cooling load components by $33 \%-50 \%$ [12]. Peng et al. conducted an investigation on the annual thermal performance of a photovoltaic wall mounted on a multilayer facade [13]. The results indicated that the south-facing PV wall could reduce heat gain through the envelope by $51 \%$ in summer in Hong Kong. And an optimal thickness for the air gap of southfacing PV wall $(0.06 \mathrm{~m})$ is recommended in Hong Kong in terms of the overall thermal performance. Bloem [14] and Sun et al. [15] studied the electrical and thermal performance evaluation of photovoltaic (PV) systems integrated as cladding components of the buildings. The optimum designs suggestions were put out through the researches. Azadian and Radzi [6] categorized four main barriers and gave suggestions to enhance the efficiency of generating and maintaining power. Related researches also indicate the PV module integrated building facade has great benefit in energy and resources saving [16-21].

Although various research on PV wall have been conducted, seldom research are focused on the safety and power generation performance of BIPV systems when and after earthquakes hit. As known to us, China is a country with frequent earthquakes. The cost of high-rise buildings becomes very huge. Therefore, the new constructed buildings must meet the need of both energy saving and seismic safety especially in high-rise buildings. Currently, the PV modules of building facades are designed as nonstructural components attached to the building envelope. As a special nonstructural component, the PV facades of high-rise buildings may cause secondary disaster during earthquake, if the PV system is not properly designed. The seismic design of nonstructural components has been attract more and more attentions. Special requests are given in building seismic design by ASCE 7-10 [22] and the Chinese Code GB 500112010 [23]. But, current nonstructural requests are not so clear and not proper to PV component. Actually, PV system has the property of producing electricity that is excellent disaster prevention and mitigation solution to the earthquake hit area. However, the reliability of power supply for disaster relief after earthquake also depends on the proper seismic design [24].

Shear wall is one of the most widely used structural members in the high-rise buildings due to its high lateral bearing capacity and energy dissipation capacity [25-29]. According to the related engineering installation atlas of BIPV, the PV module is installed on building walls by bolts and steel beams, but even this installation atlas form has not been evaluated in terms of seismic safety. Moreover, expansion anchor bolt has been proved not so reliable under seismic action.

As we have seen, BIPV has been applied worldwide, while the structural property especially the seismic behavior has not been evaluated. Current BIPV forms are seldom applied on structural facades especially on high-rise structures for its safety consideration. With the consideration of seismic safety and material saving, a new kind of PV facade form, an integrated PV module with shear walls, called U-shaped steel connected PV integrated shear wall (U-PV-SW), is proposed according to the current PV installation forms. As a possible PV facade application form, this U-PV-SW is designed in detail here. To clarify the construction procedure and evaluate the structural property and the electricitygeneration capacity, a U-PV-SW model was made and tested. The design and installation measure are simulated by model construction. The seismic behavior and power generation capacity are evaluated under the reversed low cyclic loading test. And the temperature variation of the PV module and walls is tested simultaneously.

\section{Design and Construction of the U-PV-SW}

A U-shaped steel connected PV module integrated shear wall is designed in this study. The PV module was mounted on the predesigned embedded steel plates of the shear wall by bolts and U-shaped steel connectors. In this design, a multicrystalline silicon (mc-Si) PV module with maximum efficiency of $15 \%$ was chosen here. The dimensions and details of the PV module are shown in Figure 1. The total weight of PV module is $18.6 \mathrm{~kg}$. The electrical and mechanical characteristics are listed in Table 1 . The shear wall was designed as common structure member with embedded columns according to Chinese Code for Seismic Design of Buildings (GB 500112010) and Code for Design of Concrete Structures (GB 500102010) $[23,30]$. Four steel plates with dimensions $143 \mathrm{~mm} \times$ $110 \mathrm{~mm} \times 8 \mathrm{~mm}$ are fixed on the shear wall which is designed according to request of embedded element in Chinese Code for Design of Steel Structures (GB 50017-2003) [31]. The embedded plates were welted with reinforcements cage of the shear wall by four D8 (diameter $=8 \mathrm{~mm}$ ) reinforcements before the concrete were casted. Then, the $\mathrm{U}$-shaped steel connectors were welted on the embedded steel plate so as to be fixed on the reinforced concrete shear wall. Since the PV module is applied on high-rise structures, we chose steel instead of aluminum alloy as the connector material. The dimensions of shear wall and embedded plates and U-shaped connectors are shown in Figure 2.

Commonly, concrete shear walls are designed as a ductile member and often failed at the corner as concrete crush and steel bar buckling after earthquake hit. Under this consideration, the embedded steel plates are located away from the critical area so as to avoid the connection failure caused by corner concrete crush.

The U-shaped connectors were welded to the embedded steel plates after the shear wall concrete was casted, see Figure 2(a). There is a $15 \mathrm{~mm} \times 12 \mathrm{~mm}$ preformed hole on the U-shaped connector to connect PV module by bolts; see Figure 2(b). The PV module was connected to the connectors by four D8 (diameter $=8 \mathrm{~mm}$ ) bolts. Since the main structural response under earthquake is lateral deformation, the holes on the $U$ shape connector can provide relative movement space between bolts and connector like most bolt 


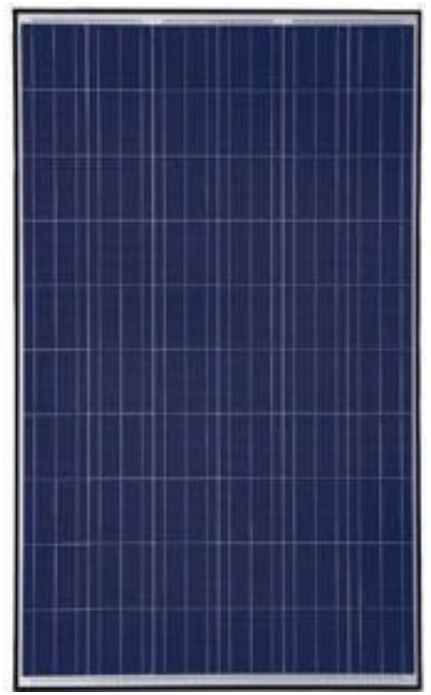

(a)

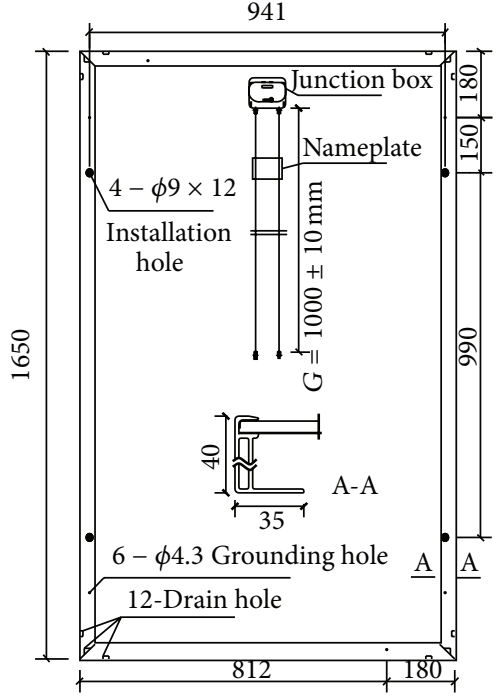

(b)

Figure 1: Dimension and details of the PV module (unit: mm). (a) Front view. (b) Back view.

TABle 1: The PV module specifications.

Solar panel model

Electrical characteristics (STC)

Peak power Watts- $P_{\mathrm{MAX}}\left(W_{p}\right)$

Power output tolerance- $P_{\mathrm{MAX}}(\%)$

Maximum power voltage- $V_{\text {MPP }}(\mathrm{V})$

Maximum power current- $I_{\mathrm{MPP}}(\mathrm{A})$

Open circuit voltage- $V_{\mathrm{OC}}(\mathrm{V})$

Short circuit current $-I_{\mathrm{SC}}(\mathrm{A})$

Mechanical characteristics

Solar cells

Cell orientation

Module dimensions

Weight

Glass

Frame

J-box

Cables

Connector
TSM-PC05A.08

$$
\begin{gathered}
260 \\
0 \sim+3 \\
30.6 \\
8.50 \\
38.2 \\
9.0
\end{gathered}
$$

Multicrystalline $156 \times 156 \mathrm{~mm}$

60 cells $(6 \times 10)$

$1650 \times 992 \times 40 \mathrm{~mm}$

$18.6 \mathrm{~kg}$

High transparency solar glass $3.2 \mathrm{~mm}$

Black anodized aluminum alloy

IP65 rated

Photovoltaic technology cable $4.0 \mathrm{~mm}^{2}, 1000 \mathrm{~mm}$

Original MC4 connected steel elements. Moreover, the installation error can also be adjusted by the enlarged hole.

Figure 3 shows the installation details of the U-PVSW (U-shaped steel connected PV integrated shear wall). Firstly, the U-shaped steel connectors were welded in the predesigned position of embedded plates. Then, the PV module was connected to the steel connectors by four bolts. Some pieces of rubber gaskets $(\mathrm{HS}=45)$ with a thickness of $3 \mathrm{~mm}$ were placed between the bolts and PV module as dampers to reduce the collision. The thickness of the air gap between the PV modules and the facade has a significant influence on the thermal performance of PV wall $[11,13]$. In this paper, the air gap was determined to be about $0.075 \mathrm{~m}$ for Shanghai weather conditions.

The construction procedure was simulated through the model fabrication. The embedded element is fixed on the shear wall smoothly, and the $U$ shape connector was also welted on the embedded plates conveniently, but it takes a little bit time. If it can be installed by bolt or locked directly, the installation period can be reduced obviously. When installing the PV module with the U-shaped connector, the bolt needs to be screwed carefully. If the space of the $U$ shape connector is lager, the bolt connecting will be easier or use lock form. 


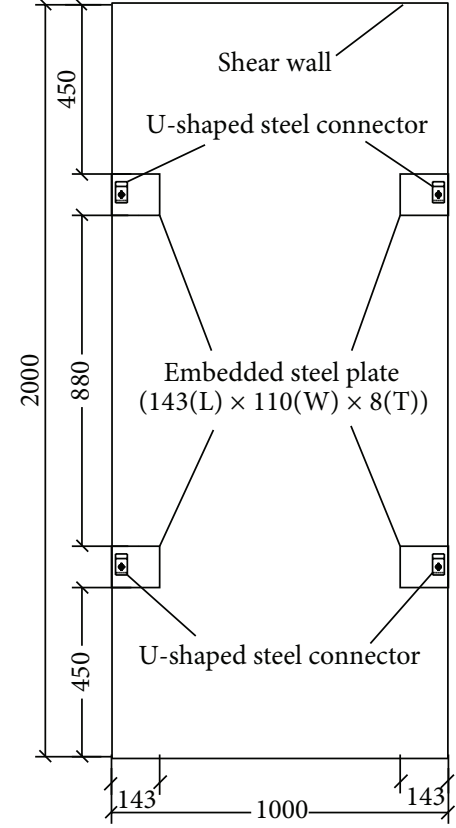

(a)

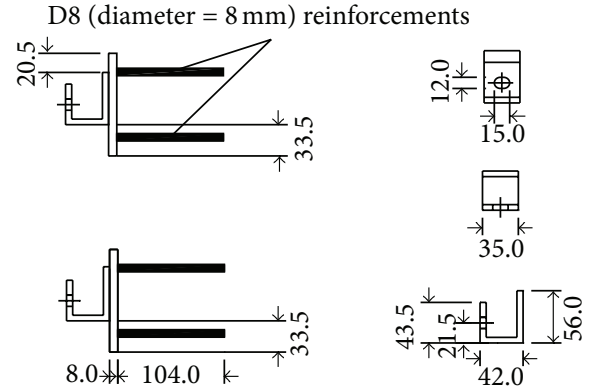

(b)

FIGURE 2: Details of shear wall, embedded plate, and U-shaped connector. (a) Shear wall and embedded steel plate. (b) U-shaped steel connector (unit: $\mathrm{mm}$ ).

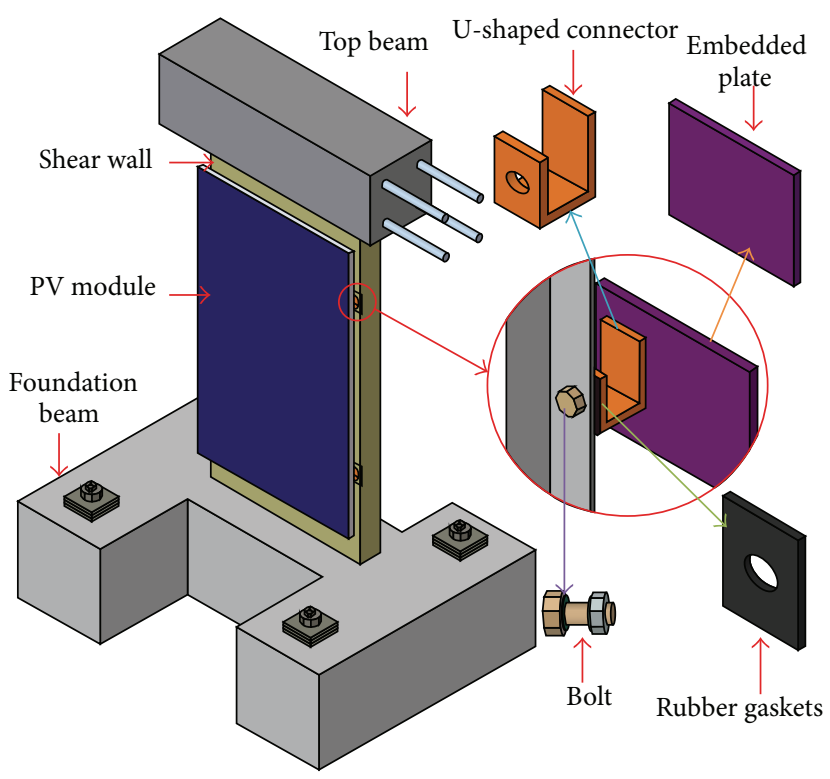

FIGURE 3: Installation details of U-SW-PV.

Through this installation simulation, several suggestions can be made. (1) The connector can be bolted or locked with the shear wall; (2) the bolt screw space needs to be considered when installing the PV module with the connector; and a lock form connection is preferable.

\section{Experimental Investigation}

3.1. Test Specimen. The specimen labeled as U-PV-SW was modeled and tested in this study. The shear wall of this specimen was designed as $1 / 2$ scaled shear wall of the typical 

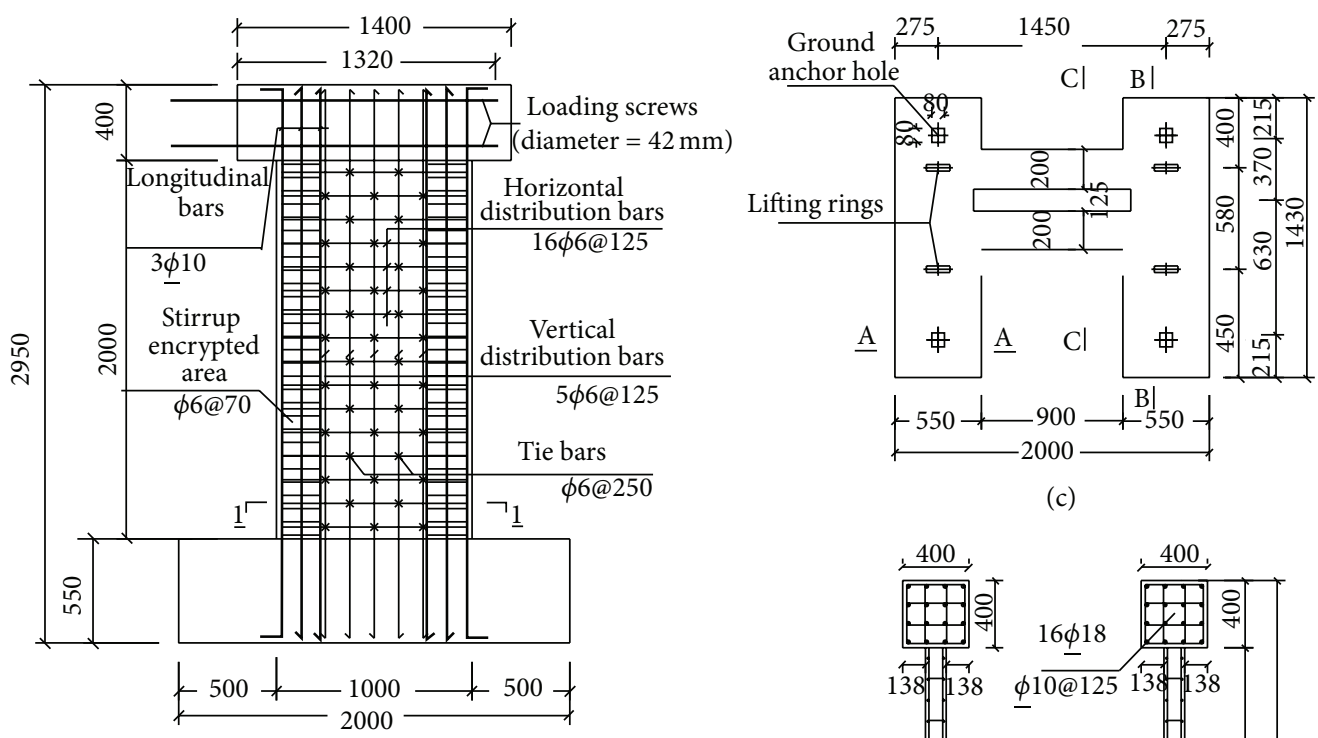

(c)

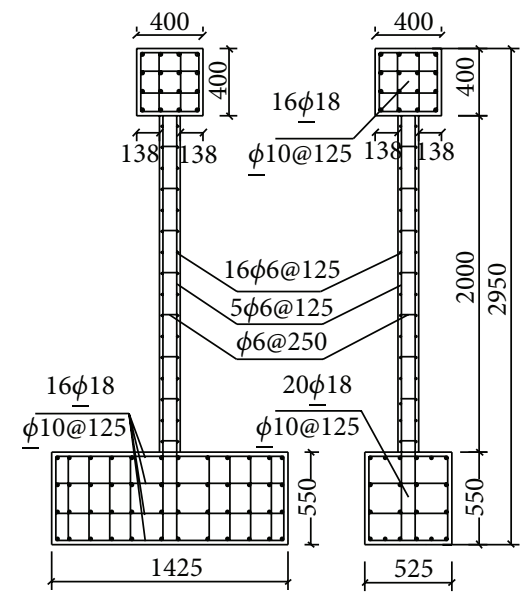

(e)

(f)

FIGURE 4: Dimension and details of specimen, U-SW-PV-1 (unit: mm). (a) Elevation view. (b) Section 1-1. (c) Plan view of foundation beam. (d) Section A-A. (e) Section B-B. (f) Section C-C.

story of a high-rise structure. Figure 4 shows the details of the specimen. The shear wall is $2000 \mathrm{~mm}$ in height, $1000 \mathrm{~mm}$ in length, and $125 \mathrm{~mm}$ in thickness. The aspect ratio (i.e., height-to-width ratio) of the shear wall is 2.0. A reinforced concrete foundation beam with a cross-section of $550 \mathrm{~mm}$ by $550 \mathrm{~mm}$ was casted together with the wall, through which the specimen was securely clamped to the reaction floor by 4 large size bolts. The reinforced concrete top beam with a cross-section of $400 \mathrm{~mm}$ by $400 \mathrm{~mm}$ was casted as well, through which the horizontal loads were applied to the wall.

As shown in Figures 4(a) and 4(b), the reinforcement details of the shear wall and the boundary elements were designed according to the provision of Chinese codes GB 50011-2010 [23] and GB50010-2010 [31]. The reinforcement of the foundation and top beams was designed strong enough to ensure the beams will not be damaged during the test, and there was no damage in the process of the actual test. Figures $4(\mathrm{~d}), 4(\mathrm{e})$, and $4(\mathrm{f})$ present the reinforcing details of these beams, respectively.

3.2. Material Property. The concrete of C40 is adopted in the specimen making (nominal cubic compressive strength $f_{\mathrm{cu}, d}=40 \mathrm{MPa}$, and design value of axial compressive strength $\left.f_{c, d}=19.1 \mathrm{MPa}\right)$. Actual cubic compressive strength $f_{\mathrm{cu}, t}$ of the concrete was tested by cubes of $150 \mathrm{~mm} \times$
TABLE 2: (a) Material properties of concrete. (b) Material properties of steels.

(a)

\begin{tabular}{lc}
\hline Strength grade & C40 \\
Test cubic compressive strength, $f_{\text {cu,t }}\left(\mathrm{N} / \mathrm{mm}^{2}\right)$ & 37.7 \\
Test axial compressive strength, $f_{c, t}\left(\mathrm{~N} / \mathrm{mm}^{2}\right)$ & 28.3 \\
Young's modulus, $E_{s}\left(\mathrm{~N} / \mathrm{mm}^{2}\right)$ & 33800 \\
\hline
\end{tabular}

(b)

\begin{tabular}{lccc}
\hline & $\begin{array}{c}\text { HPB 235 } \\
(\phi 6)\end{array}$ & $\begin{array}{c}\text { HRB335 } \\
(\Phi 10)\end{array}$ & $\begin{array}{c}\text { Q235 } \\
\text { (steel plate })\end{array}$ \\
\hline $\begin{array}{l}\text { Yield strength, } \\
f_{y, t}\left(\mathrm{~N} / \mathrm{mm}^{2}\right)\end{array}$ & 297.7 & 451.7 & 425.5 \\
\hline $\begin{array}{l}\text { Ultimate strength, } \\
f_{u, t}\left(\mathrm{~N} / \mathrm{mm}^{2}\right)\end{array}$ & 430 & 545 & 440.6 \\
\hline $\begin{array}{l}\text { Young's modulus, } \\
E_{s}\left(\mathrm{~N} / \mathrm{mm}^{2}\right)\end{array}$ & $2.0 \times 10^{5}$ & $1.6 \times 10^{5}$ & $1.8 \times 10^{5}$ \\
\hline
\end{tabular}

$150 \mathrm{~mm} \times 150 \mathrm{~mm}$ concrete blocks and the results are listed in Table 2(a). And the actual value of axial compressive strength of concrete $f_{c, t}$ was tested on a prism with dimension of $300 \mathrm{~mm} \times 100 \mathrm{~mm} \times 100 \mathrm{~mm}$. It is worth noting that the actual 


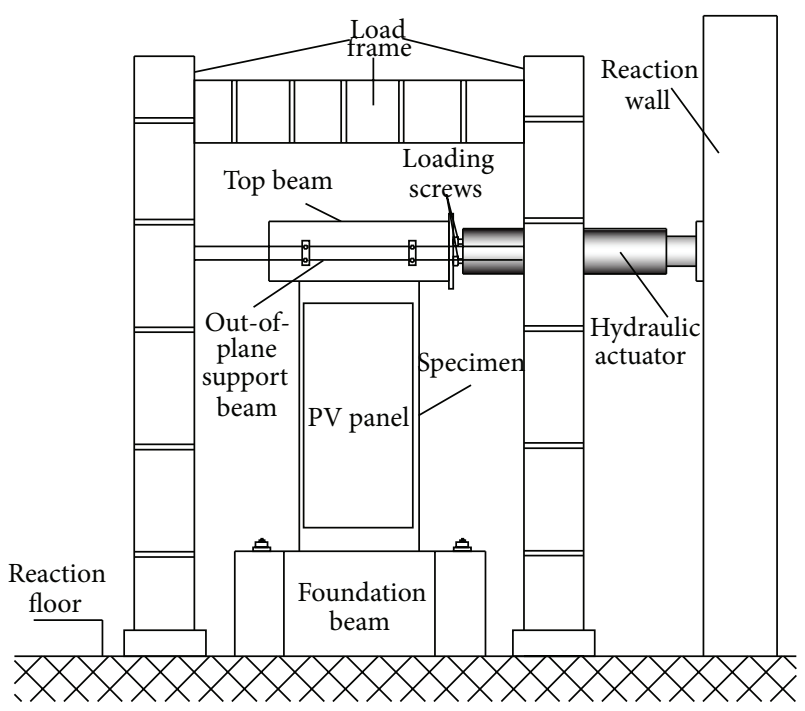

Figure 5: Test setup.

value of axial compressive strength of concrete $f_{c, t}$ was about 0.75 times of $f_{\mathrm{cu}, t}$ in consistent with the value of 0.76 , which is recommended by the Chinese Code for Design of Concrete Structures (GB50010-2010) [31].

Four steel embedded plates were made with the steel of grade Q235 (nominal yield strength $f_{y}=235 \mathrm{MPa}$, design value of yield strength $f_{y, d}=215 \mathrm{MPa}$ ). There were two types of reinforcements in the shear wall, and their strength grades were $\operatorname{HPB} 235\left(f_{y}=235 \mathrm{MPa}\right)$ and $\operatorname{HRB} 335\left(f_{y}=335 \mathrm{MPa}\right)$, respectively. The actual test values of both steel plates and reinforcements are listed in Table 2(b). The bolts of D8 are used to connect $\mathrm{U}$ shape steel connector and PV module (nominal ultimate strength of D8 bolts, $f_{u}=400 \mathrm{MPa}$, and the ratio $f_{y} / f_{u}=0.8$ ).

3.3. Test Setup, Loading Program, and Instruments. Figure 5 shows the test setup, where the specimen was located in the steel frame. The foundation beam was clamped to the floor by bolts. The top beam was connected to a hydraulic actuator in the horizontal direction by four loading screws (diameter $=42 \mathrm{~mm}$ ). Several rollers with out-of-plane support beams were set on both sides of the top beam of the shear wall to prevent out-of-plane deformation during the whole test. The low cyclic lateral load was acted by the actuator mounted horizontally to the reaction wall. The horizontal loading point (i.e., the mid-height of the top beam) was $2200 \mathrm{~mm}$ above the base of the wall, so the shear span ratio of the wall was 2.2.

Figure 6 shows the loading history of the test, which was controlled by displacement. Before the specimen was yield, the displacement was increased by $1 \mathrm{~mm}$ with each cycle. After the specimen was yield, the displacement was increased as by $2 \mathrm{~mm}$ with every three cycles. The ultimate displacement was designed as $40 \mathrm{~mm}$, while, in order to ensure the safety of the specimen, and the last two loading sequence $(37 \mathrm{~mm}$ and $40 \mathrm{~mm}$ ) was maintained only one cycle. In each loading sequence, the specimen was pushed first and then pulled by the actuator. The test was terminated when the loading

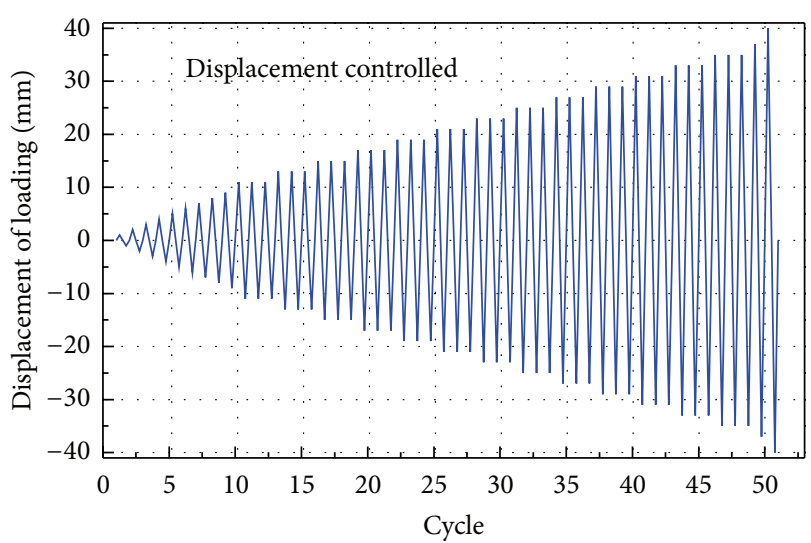

Figure 6: Loading sequence.

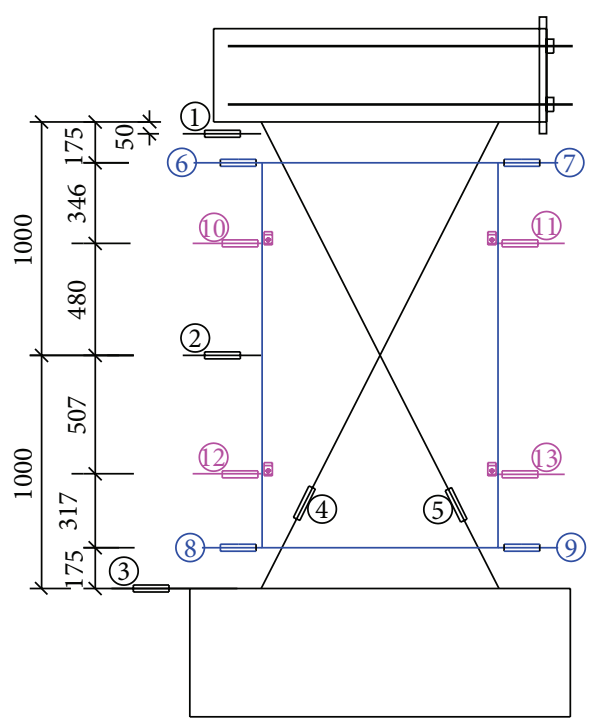

FIGURE 7: Location details of LVDTs.

displacement reached $40 \mathrm{~mm}$, (40 mm is $1 / 50$ of the height of the specimen). It is regarded that a structure may collapse when the story drift angle exceeds the criterion of 1/50 [23].

During the experiment of the specimen, several sensors and data acquisition system were employed to collect the structural behavior information. The sensors in the actuators were used to measure the lateral load and top displacement of the specimen. The LVDTs (linear variable different transformers) were used to measure the global and local deformations of the shear wall. Figure 7 gives out the location of the LVDTs distributed on the specimen. Three LVDTs (LVDTs $1^{\#}$ to $3^{\#}$ ) were used to measure the displacement variation along the height of the wall. One pair of intercrossed LVDTs (LVDTs $4^{\#}$ and $5^{\#}$ ) measured the shear deformation of the wall. Two pairs of horizontal LVDTs (LVDTs $6^{\#}$ to $9^{\#}$ ) measured the lateral displacement along the height of the PV module in both left and right sides. Another two pairs of horizontal LVDTs (LVDTs $10^{\#}$ to $13^{\#}$ ) were employed to measure the lateral displacement of the four connectors. In addition, several strain gauges were stuck on the steel bars 


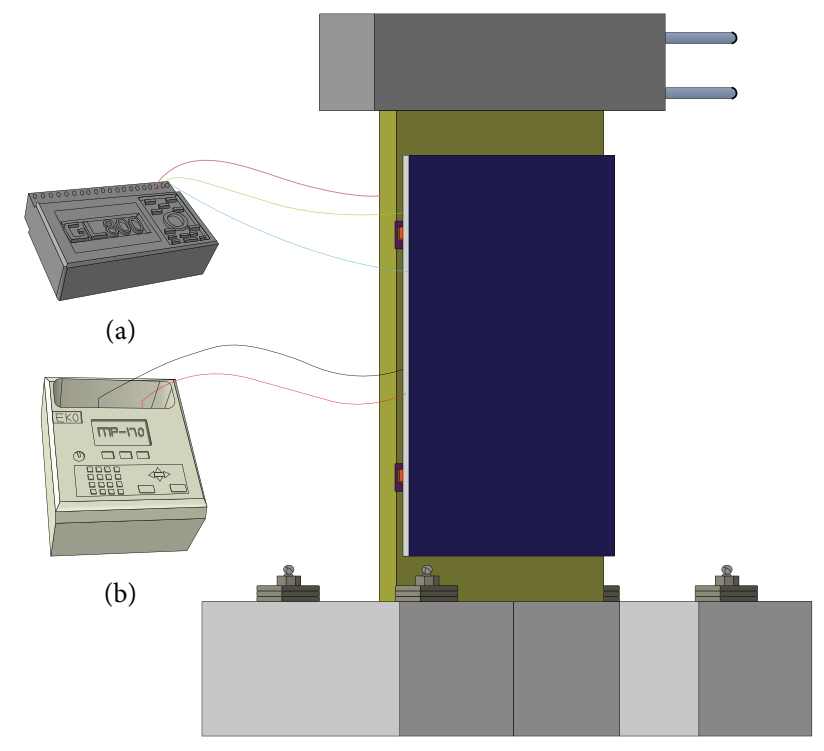

FIGURE 8: Instruments for measuring temperature and electricity. (a) GRAPHTEC midi logger GL800. (b) EKO MP-170.

of the shear wall to measure the vertical, horizontal strain variation during the test.

Figure 8 shows the instruments for measuring temperatures and electricity performance of the PV module. As the test was conducted in winter, the sunshine is not so rich, and artificial sunshine environment was established in the laboratory by using several high-power halogen lamps, which were equally spaced to ensure the uniform of irradiance (see Figure 9). The artificial lighting system was consisted by four $500 \mathrm{~W}$ halogen lamps in the middle height of the PV module and four $1000 \mathrm{~W}$ halogen lamps at the upper and bottom height of the PV module. The position was fixed during the whole testing process to confirm the same lighting condition. Three thermocouples were used to measure and record the temperature variation of U-SW-PV. Two of them were stocked on the internal and external surfaces of the shear wall. Another one was stuck on the back surface of the PV module. The temperature data of the three thermocouples was collected by a data logger (GRAPHTEC midi logger GL800, see Figure 8).

The power generation behavior of PV module was tested by $I-V$ tracer (EKO MP-170, made in Japan). The voltage and current variation curve, the maximum power $-P_{\mathrm{MAX}}$, the voltage at the maximum power point $-V_{\mathrm{MPP}}$, and current at the maximum power point $-I_{\mathrm{MPP}}$ were also recorded by the $I-V$ curve tracer. Actual test setup and instruments are shown in the Figure 9.

\section{Experimental Results}

\subsection{Seismic Performance of $U-S W-P V$}

4.1.1. Overview. The typical development of the observed damage was shown in Figure 10. Initial horizontal cracks appeared at the bottom of both sides of the wall when the top displacement reached $8 \mathrm{~mm}$, as shown in Figure 10(a).
Subsequently, the outmost longitudinal reinforcement of the boundary element became yield according to the tested steel bar property. Next, the diagonal cracks were generally observed immediately after the initial yielding of the outmost longitudinal bars. And Figure 10(b) shows the cracks on the shear wall when the drift angle is $1 / 120$ (that is a safety limit under severe earthquake according to Chinese seismic code). And the PV module still remained perfect at this moment (see Figure 10(c)). With the increasing of the horizontal loading, new horizontal and diagonal cracks developed fast, and the maximum width of the cracks were near $2 \mathrm{~mm}$. Then, it is observed that the concrete cover at the bottom of the shear wall became crushed. Following the concrete cover spalling, the stirrups and longitudinal reinforcements were exposed, and the bars buckled or broke finally.

\subsubsection{Damage and Failure Pattern}

(1) Shear Wall. The shear wall of the U-SW-PV specimen experienced reinforcements local buckling and concrete compressive crushing. The damage process can be divided into elastic stage, plastic stage, and severe failure stage. (1) The elastic stage started from the initial loading to the yield state of the specimen. In the elastic stage, the top drift angle of the specimen is within $1 / 200$, which meets the requirement of the Chinese seismic code (i.e. 1/1000). Drift angle is defined as the ratio of the lateral top displacement to the height of the shear wall. When the drift angle is $1 / 200$, the strain of the reinforcements indicated the steel bars at the outer edges of the bottom of the wall also yielded. (2) After the specimen yielded, cracks and concrete spalling developed fast with the increasing of the loading. And the longitudinal bars came to be exposed. When the drift angle reached 1/116, the lateral force reached the peak value. (3) Then, it is the severe failure stage, which started from the specimen reaching the peak load to the specimen's almost collapse. In the end, the longitudinal bars fractured and the concrete in the plastic hinge area was crushed extremely.

(2) Connection. The embedded plates and the U-shaped connector have not subjected any damage during this test (see Figure 11). Only tiny cracks appeared on the concrete around the embedded steel plates, and no concrete spalling or crushing was observed. Figure 11 demonstrates the details of the specimen after the test finished. From this figure, we can see the U-shaped connectors remained perfect when the specimen reaches the ultimate state.

(3) PV Module. The PV module is installed on the shear wall by $4 \mathrm{U}$ shape steel connectors. There is no any physical damage found during and after the cyclic lateral loading test. The tempered glass, the solar cells, and the aluminum alloy frame were still in perfect physical condition.

4.1.3. Lateral Force-Top Displacement Relationship and the Deformation Capacity. The relationship curves of the lateral force and the top displacement of the shear wall, including the hysteresis loop curves and the envelope curve, are shown in Figures 12(a) and 12(b), respectively. The hysteresis loop 


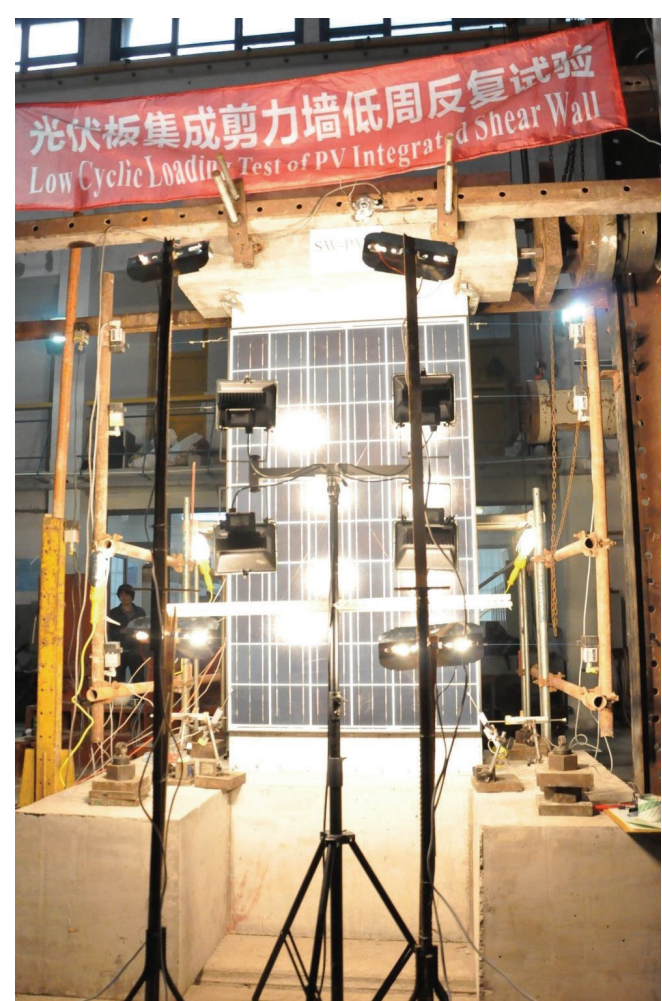

(a)

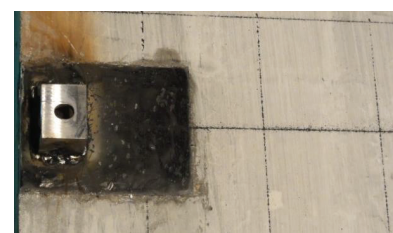

(b)

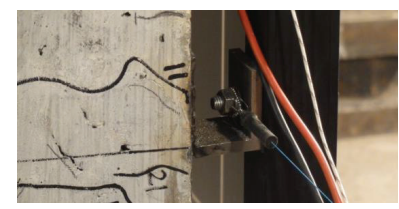

(c)

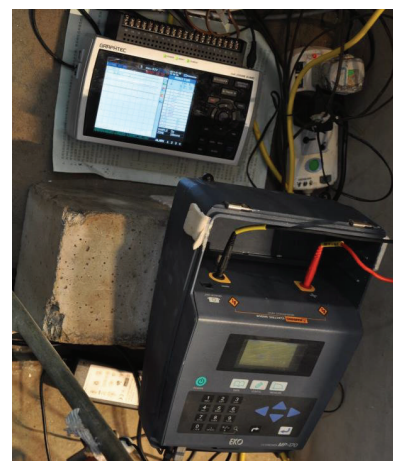

(d)

FIgURE 9: The real test setup and instruments for U-SW-PV-1. (a) Test setup. (b) Connection of U-shaped connector and embedded steel plate. (c) Connection of U-shaped connector and PV module. (d) Instruments (GL800 and EKO MP-170).

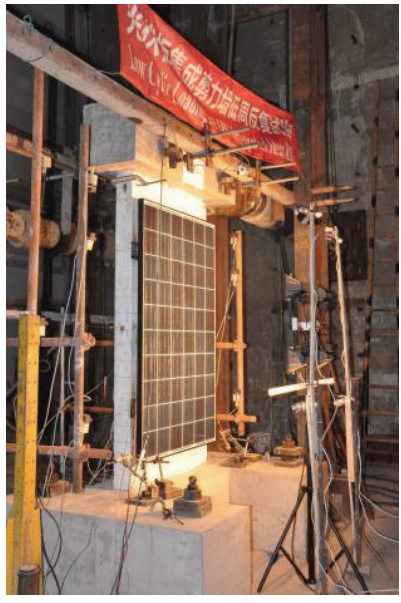

(a) Initial state

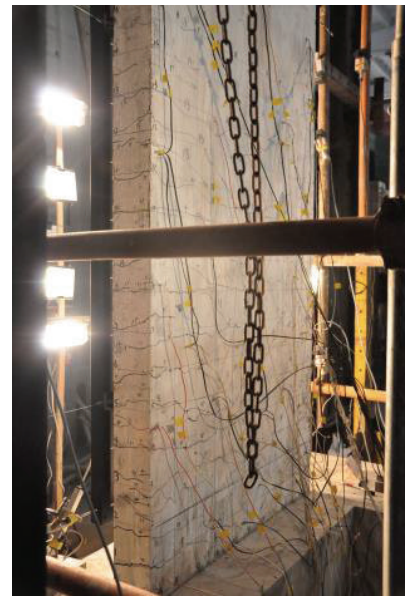

(b) Cracks on shear wall

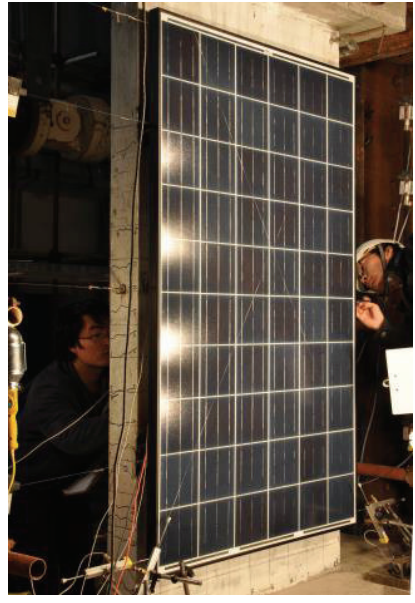

(c) PV module

Figure 10: Typical damage development. (a) No damage (drift angle: 1/1000). (b) Cracks on shear wall (drift angle: 1/120). (c) No damage on PV module (drift angle: 1/120).

curves of the wall appeared as reversed "S" and were similar to the same type shear walls [25-29]. The yielding and ultimate state are illustrated in Figure 13. The hysteresis curves of the shear wall are almost linear and the residual drift angle is less than $1 / 1000$. When the shear wall is yield, the loading stiffness is apparently decreased, and the lateral bearing force is still increased. When the drift angle increases to $1 / 120$ (i.e., the drift angle limit for the RC shear wall structure subjected to an earthquake specified by code GB50011-2010 [23]), the residual drift angle of unloading is about $1 / 400$. With the increase of the loading level, the hysteretic loops became plumper until the specimen failed.

The displacement ductility coefficient is defined as

$$
\mu_{\Delta}=\frac{\Delta_{u}}{\Delta_{y}} .
$$



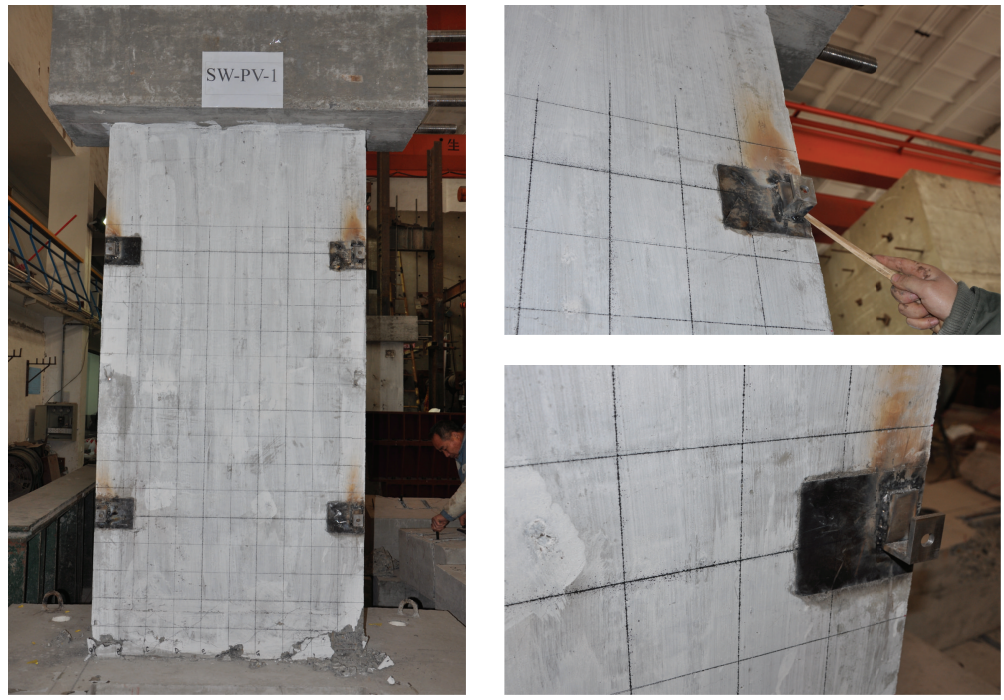

FIGURE 11: Damage details of the U-shaped connectors when the specimen reached its ultimate state.

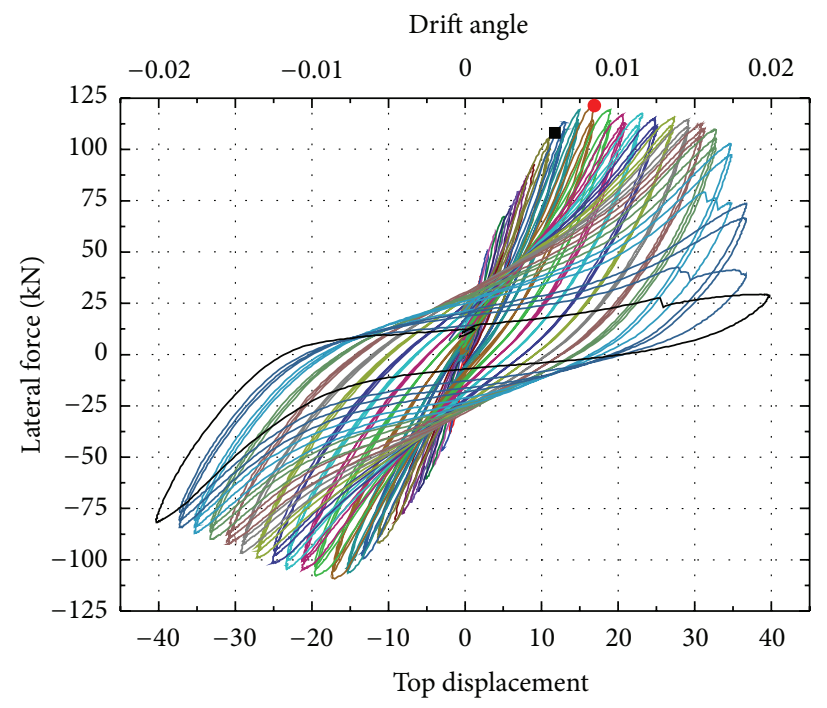

- Yield load

- Peak load

(a)

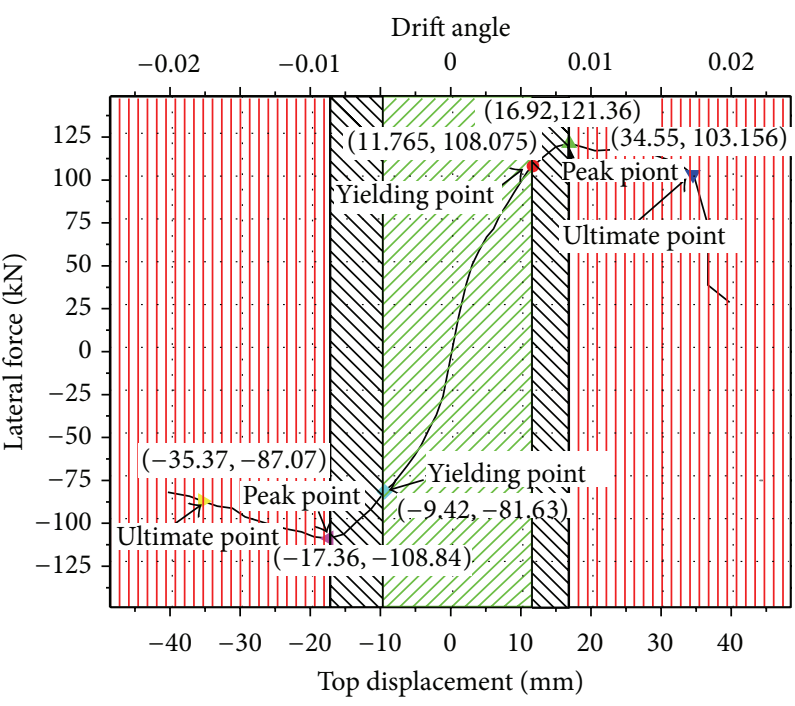

(2) Elastic stage: drift angle within $0 \sim 1 / 200$ Plastic stage: drift angle within 1/200 1/116 血 Severely failure stage: drift angle within $1 / 116 \sim 1 / 50$

(b)

FIGURE 12: Lateral force-top displacement curve of the shear wall. (a) Hysteresis loop curves. (b) Envelope curve.

Here, $\Delta_{u}$ and $\Delta_{y}$ are ultimate displacement and yield displacement, respectively. The ultimate drift angle is

$$
\theta_{u}=\frac{\Delta_{u}}{H}
$$

where " $H$ " is the height of the LVDT $1^{\#}$ to the wall basement. The ultimate drift angle $\theta_{u}$ is the average value of the pulling and pushing directions. The critical deformation values are listed in Table 3.

\subsection{Seismic, Electricity Generation, and Temperature Performance}

4.2.1. Seismic Performance. Glass is the main carrier of PV module, so the PV module integrated building facades can be considered as a special type of curtain wall. According to the Chinese Technical Code for Glass Curtain Wall Engineering (JGJ 102-2003) [32], the ultimate story drift angle limit value in the glass curtain wall is three times of the elastic drift angle limit of the main structure in seismic design. Since the elastic story drift angle limit value of shear wall structure is $1 / 1000$, 


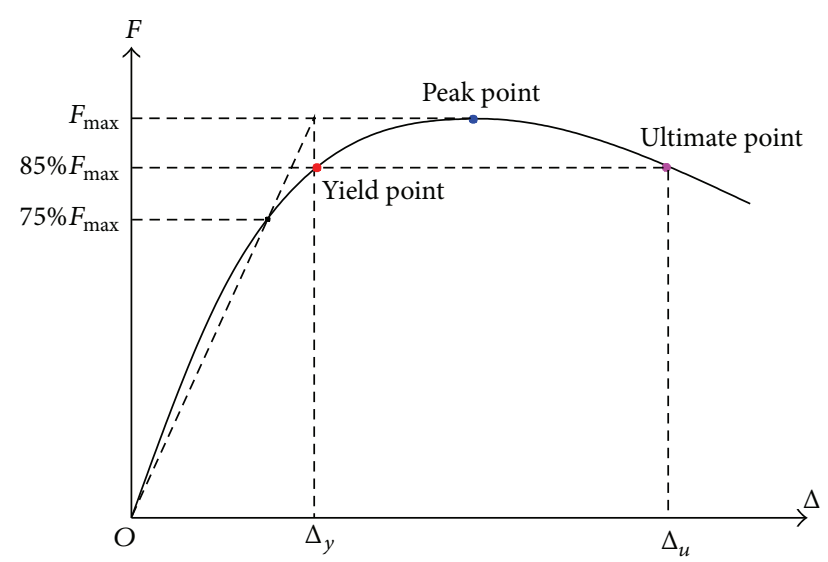

FIGURE 13: Definition of yielding and ultimate state of the shear wall. (Note: yield point is the point on the curve with the same abscissa with the intercross point of the horizontal line at peak point and the connecting line between $75 \%$ peak point and origin; ultimate point is the point on the curve when the lateral force decreases to $85 \%$ of the maximum value).

TABLE 3: Critical deformation and ductility coefficient.

\begin{tabular}{lcc}
\hline Specimen & U-SW-PV & Description \\
\hline Yield disp. $\Delta_{y}(\mathrm{~mm})$ & $11.77 / 9.42$ & Push/pull \\
Ultimate disp. $\Delta_{u}(\mathrm{~mm})$ & $34.55 / 35.37$ & Push/Pull \\
Ultimate drift ratio $\theta_{u}$ & $1 / 56$ & Average \\
Disp. ductility ratio $\mu_{\Delta}$ & 3.345 & Average \\
\hline
\end{tabular}

thus the ultimate limit value of PV module is 3/1000, which is a relatively conservative design value to actual damage value.

To test the deformation of the PV module during the cyclic lateral loading procedure, the maximum horizontal displacements of PV module and U-shaped connectors in every loading cycle were monitored and recorded by LVDTs (i.e., LVDTs $6^{\#}$ to $9^{\#}$ for PV module and LVDTs $10^{\#}$ to $13^{\#}$ for U-shaped connectors, see Figure 7). The locations of measurement points were shown in Figure 14(a), and the maximum displacements were shown in Figure 14(b). The curves in Figure 14(b) were the connection line of the maximum displacements during every loading cycle. Accordingly, three deformation stages were divided here. The first is the absolute elastic deformation. In this stage, the shear wall drift angle is about $1 / 200$, and the PV module and connectors were basically in linear state. When the absolute displacements are between 10 and $20 \mathrm{~mm}$, the shear wall was in the damage developing stage (second stage). And, in this stage, the envelope curves appeared obvious fluctuation. With the development of the cracks and the yielding of the longitudinal reinforcement, the deformation of the shear wall came into nonlinear state, which did not keep linear deformation relationship with the PV module. The last deformation stage is defined by the absolute displacements between 30 and $40 \mathrm{~mm}$. In this stage, the curves of the lower position (PV 3, 4 and connectors 3, 4, as shown in Figure 14(a)) were obviously nonlinear due to the severe damage of the shear wall foot.

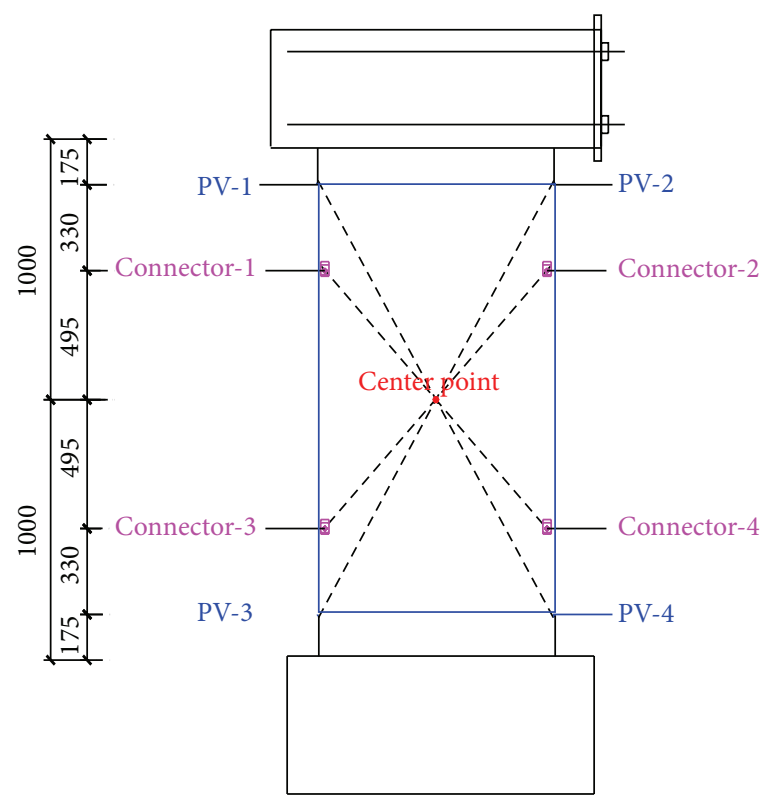

(a)

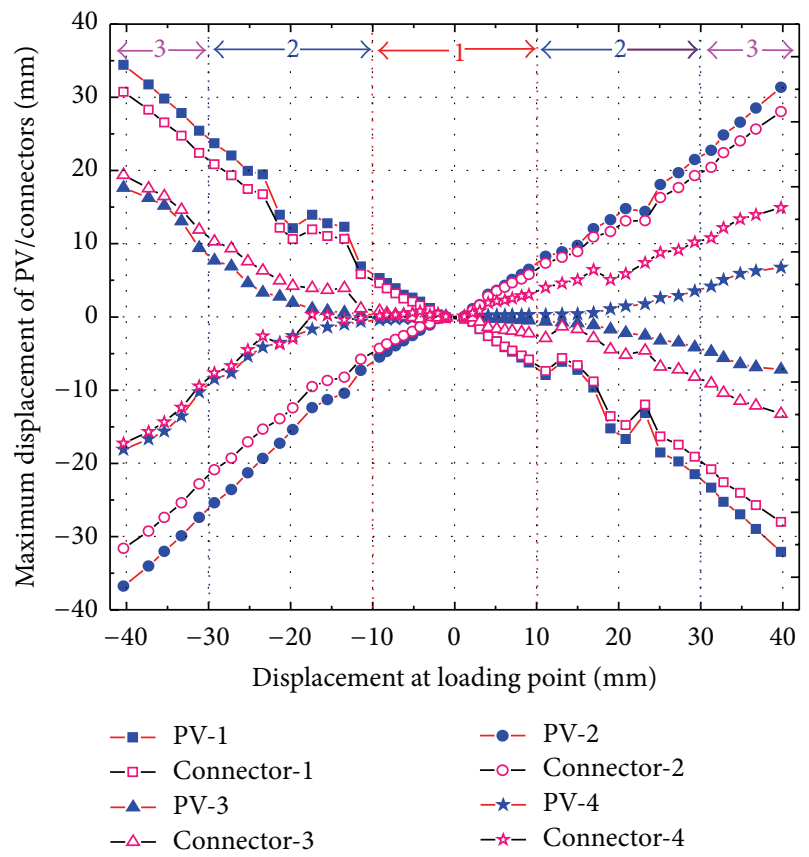

(b)

FIgURE 14: The maximum horizontal displacements of PV module and U-shaped connectors. (a) Location of deformation monitors. (b) The maximum horizontal displacements.

To illustrate the deformation compatibility of the shear wall and the PV module, the drift angle development of the shear wall and the PV module are drawn in Figure 15. In this figure, the difference of the drift angle during the whole loading process (presented by 1) can be observed. Since the loading was added on the beam of the shear wall, the drift angle development of the shear wall is the most obvious. The drift angle development of the PV module is in accordance 


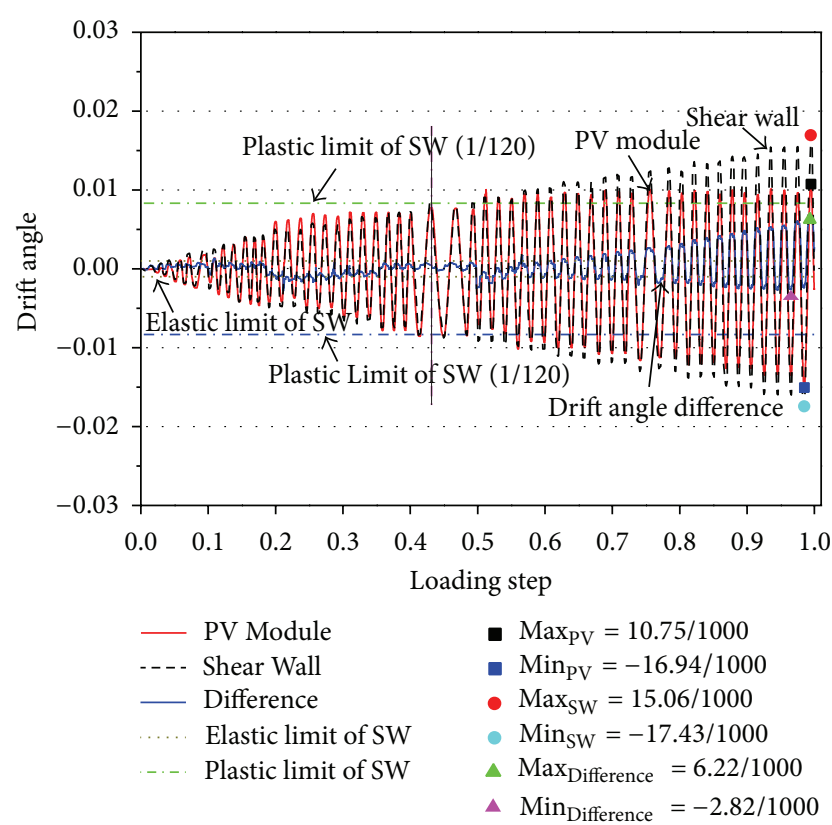

FIgURE 15: The displacement difference between the PV module and the shear wall.

with that of the shear wall at first; to be exact, the two curve matched with each other before the shear wall came into the limit value of plastic drift angle (i.e., 1/120 [23]).

From Figure 15, we can find that, with the increase of lateral load, the drift angle of the shear wall grows up gradually (the maximum drift angle is 15.06/1000), while the growth of the PV module drift angle is not so obvious (the maximum drift angle is $10.75 / 1000$ ). The difference of the drift angle of the shear wall and PV module was also drawn out in Figure 15. With the increase of the lateral displacement, the difference of the two drift angle grew up gradually. The minimum difference of the drift angle is $2.82 / 1000$ when the shear wall is in severe damage stage (i.e., no collapse stage according to China code [23]). However, when the shear wall failed, the value is $6.22 / 1000$. The growth of the difference of the two drift angle indicates that the incompatibility of the PV module and the shear wall became obvious with the plastic development of the specimen.

The investigation of the drift angle development can provide the following information. (1) According to Chinese seismic design code [23], the U-PV-SW is exactly perfect before the drift angle reaches $1 / 1000(1 / 1000$ is the critical limit of elastic state of shear structures in Chinese Seismic Code) and did not collapse or get severely damaged before the drift angle reaches 3/1000 and 1/120 (3/1000 and 1/120 is the critical limit of plastic state of glass curtain wall and shear wall structures in Chinese Seismic Code); (2) the drift of the $\mathrm{PV}$ module is in accordance with that of the shear wall before the drift angle reaches 1/120; (3) when the drift angle of the shear wall is over the plastic limit of Chinese seismic code (i.e., 1/120), the difference of the two-drift angle became more and more obvious. The maximum difference of the two-drift angle is $6.22 / 1000$, which indicates that deformation of the

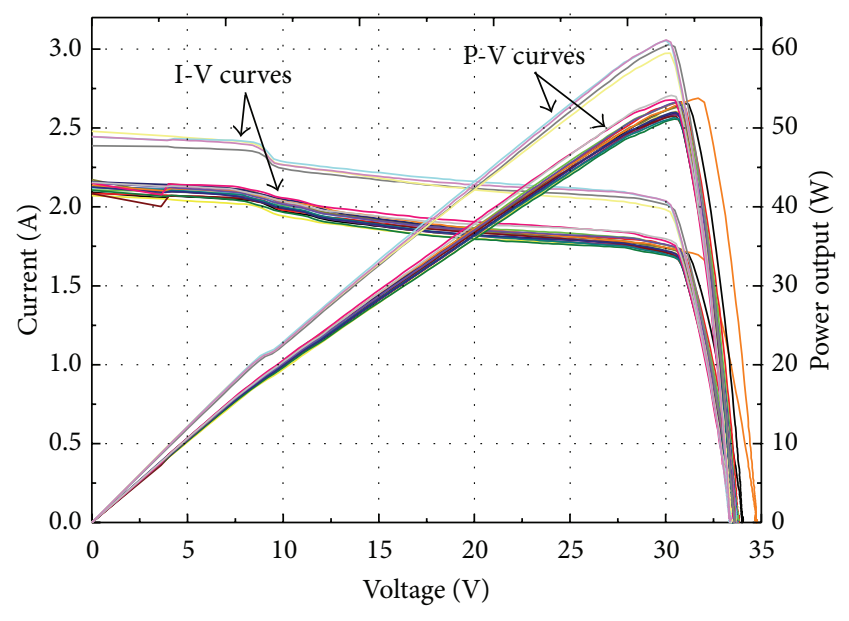

Figure 16: The $I-V$ curves and $P-V$ curves of the PV module.

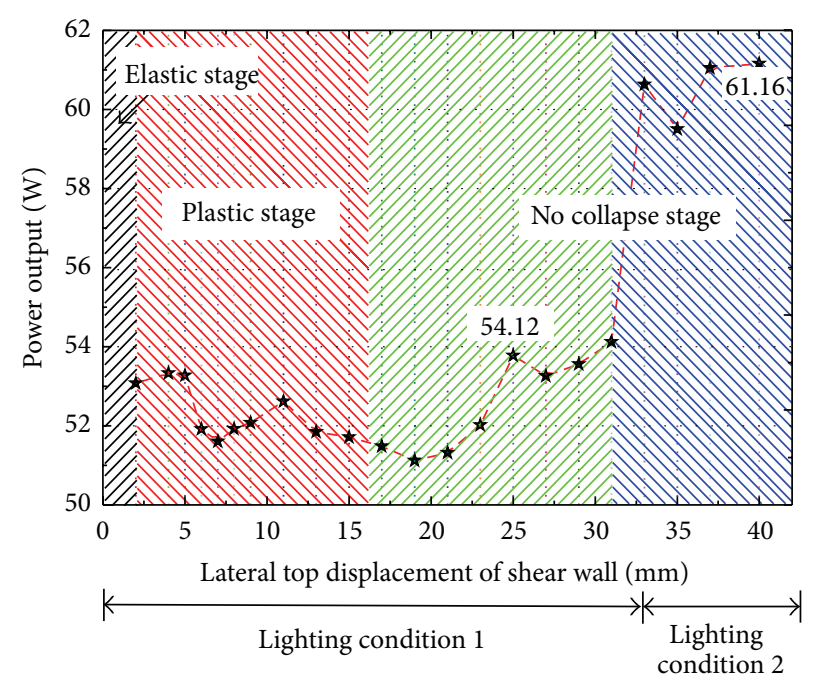

FIGURE 17: Maximum power output of PV module.

shear wall and the PV module is obviously inconsistent at the large deformation stage.

4.2.2. Electricity Generation Performance. The $I-V$ curves and $P-V$ curves of the PV module during the whole test process is shown in Figure 16. The artificial lighting environment was established before the test. The $I-V$ and $P-V$ data of the PV module were measured and recorded by the EKO MP-170 $I-V$ curve tracer before and during the whole cyclic test. It is worth noting that the voltage of the artificial lighting power supply became higher than before when the socket was changed to another one after the lateral top displacement reached $33 \mathrm{~mm}$ for circuit problem. So, the artificial lighting condition can be divided into two stages as seen in Figures 16 and 17. So, the generated power in the first lighting condition is far less than the second lighting condition. The curves of both $I-V$ and $P-V$ are also obviously different under the two lighting conditions as shown in Figure 16. 
TABLE 4: Electric power output of the PV module under the two artificial lighting conditions.

\begin{tabular}{lcccc}
\hline Power $(\mathrm{W})$ & Elastic stage & Plastic stage & \multicolumn{2}{c}{ No collapse stage } \\
& & & Condition 1 & Condition 2 \\
\hline Average value & 53.029 & 52.256 & 52.584 & 60.585 \\
Percentage & $100 \%$ & $98.54 \%$ & $99.16 \%$ & $/$ \\
\hline
\end{tabular}

Note:

(1) The percentage was defined as the average power output ratio to that of elastic stage.

(2) According to Chinese seismic code [23], the drift angle of elastic stage is within 1/1000 and the plastic ultimate stage is $1 / 120$.

The maximum power outputs of the PV module were shown in Figure 17. Because the temperature of the experimental environment is relatively cold, and the test was conducted in the indoor laboratory, the artificial lighting is employed to simulate the sunshine, as shown in Figure 9. Under the artificial lighting conditions, the current and the voltage generated by the PV module were collected. The average maximum power generated by the PV module was around $52.45 \mathrm{~W}$ under the first lighting condition (the lateral top displacement of shear wall is within $1 \mathrm{~mm}$ to $31 \mathrm{~mm}$ ). And the average maximum power was up to around $60.58 \mathrm{~W}$ under the second lighting condition (the lateral top displacement of shear wall is within $31 \mathrm{~mm}$ to $40 \mathrm{~mm}$ ). The electric power output performance of the PV module under the two artificial lighting conditions is listed in Table 4. In this table, the power generation performance is compared under different specimen drift angle with the same lighting condition.

From Figures 16 and 17 and Table 4, we can find that the power generation performance keeps stable under cyclic movement, and the power capacity is not obviously influenced by the failure of the shear wall. To be exact, the power output in plastic stage is $98.54 \%$ compared to the elastic stage and $99.16 \%$ in "no collapse" stage (severe damage stage).

4.2.3. Temperature Variation. As mentioned above, the temperature sensors were stuck on internal and external surface of the shear wall center and the back of the PV module center. The temperature variation of the back surface of PV module and the internal and external surfaces of shear wall during the whole test process were monitored and shown in Figures 18 and 19. In addition, the temperature difference curve between the back of PV module and external surface of shear wall was drawn in Figure 18, and the temperature difference curve between the external and internal surface of shear wall was drawn in Figure 19.

During the whole test, the ambient temperature was around $7^{\circ} \mathrm{C}$ (Dec 26, 2013, Shanghai). The test was conducted from 8:30 am to 14:30 pm, and there was a break in lunch time. The temperature was measured through the whole process of the cyclic test. According to the measurement results, the temperature of PV module rose fast under the artificial lighting and maintained around $40^{\circ} \mathrm{C}$ soon. The temperature of the external surface of the wall increased from $8^{\circ} \mathrm{C}$ to $15.9^{\circ} \mathrm{C}$. The temperature of the external surface of the shear wall increased obviously at first and then came to increase slowly. It rose from $7.7^{\circ} \mathrm{C}$ at $8: 35 \mathrm{am}$ to $10.7^{\circ} \mathrm{C}$ at 9:38 (rose $3^{\circ} \mathrm{C} / 1 \mathrm{~h}$ ) and rose from $14.6^{\circ} \mathrm{C}$ at $13: 08$ to $15.1^{\circ} \mathrm{C}$ at 14:08 (rose

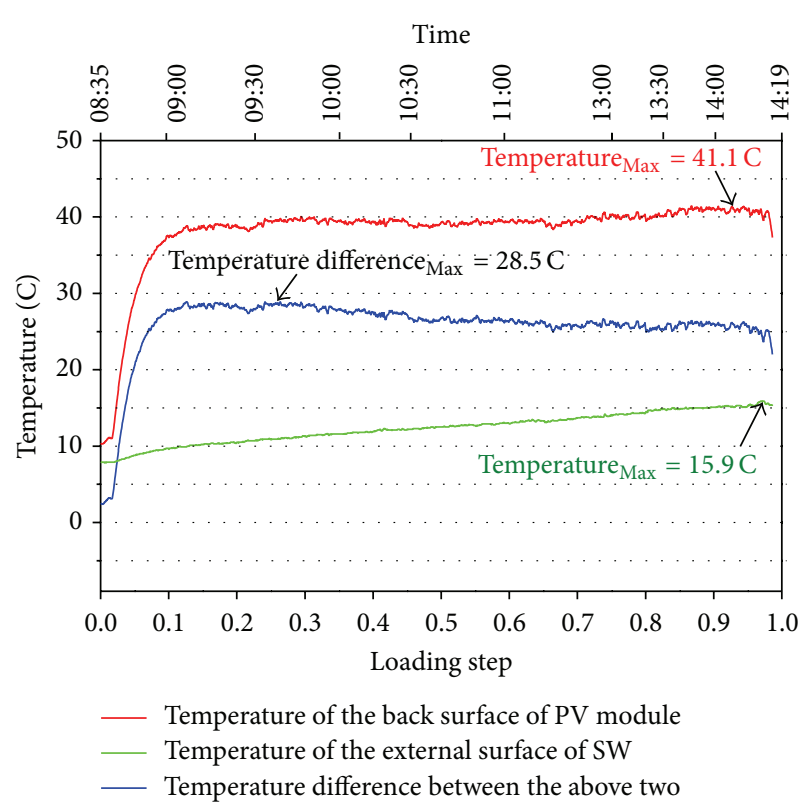

FIGURE 18: The temperature data of PV module and the external surface of shear wall.

$\left.0.5^{\circ} \mathrm{C} / 1 \mathrm{~h}\right)$. Therefore, the temperature tends to be basically constant.

Figure 19 shows the temperature of shear wall in both external and internal surfaces. The temperature of internal surface of the shear wall increased with the cyclic experiment process, and its final temperature reached up to $13.6^{\circ} \mathrm{C}$ at 14:19 pm. The temperature difference between the external and internal surface was maintained around $2^{\circ} \mathrm{C}$ during most of the test process.

Each temperature curve in Figures 18 and 19 showed that the temperature variation was not obviously influenced by specimen drift state or damage development state, and the PV module and the shear wall tend to maintain at a certain temperature value under the irradiation condition.

\section{Discussions}

This paper investigated the seismic, electricity generation, and thermal performance of the U-shaped steel connected PV module integrated shear wall (U-PV-SW), as well as the construction procedure. From the above tested results, 


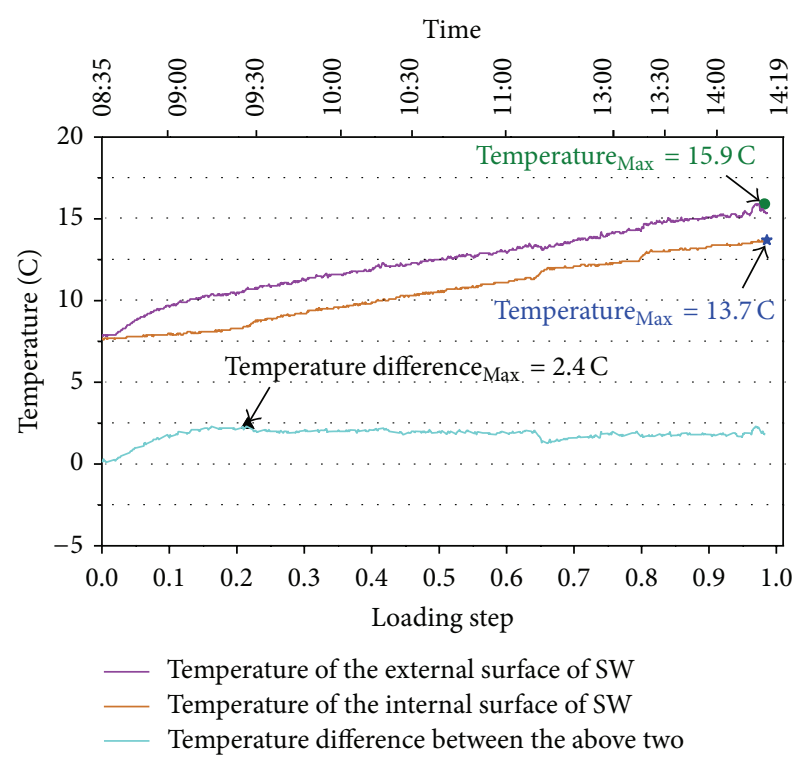

FIgURE 19: The temperature data of the shear wall in both internal and external surfaces.

the U-PV-SW demonstrates the applicability to be used in residential or office buildings.

(1) Seismic Performance. The failure pattern of the shear wall demonstrates that the damage pattern has not been obviously influenced by the integrated PV module. The critical failure pattern is also at the bottom corner as concrete crushing and steel bars buckling. It is almost the same as the tests the authors had conducted for the similar shear walls [2730]. The drift angle of the shear wall is $1 / 200$ and $1 / 116$, which meets the requirement of Chinese seismic design code [23]. As Chinese seismic design code gives out the limits at elastic stage and plastic stage, these two limits of shear structures are $1 / 1000$ and 1/120. Actually, these two limits are applied to confirm no damage at frequent earthquake and no collapse at severe earthquake. According to this idea, the U-PV-SW specimen absolutely meet the requirement for it has no damage before the drift angle is 1/200 and does not collapse till the specimen reached the ultimate state, when the drift angle is close to $1 / 50$.

The PV module is integrated to the shear wall by $\mathrm{U}$ shaped steel connector. Because the main component of PV module is a brittle material, the connector is designed to have enough deformation capacity to prevent the large deformation of PV module when the shear wall gets under severe earthquake. The tested result indicates the PV module and the $U$ shape steel connector suffered no visible damage during the whole seismic simulation test. The drift angle of PV module is basically in accordance with that of the shear wall when the shear wall is within plastic stage. And it is not increased as obviously as that of the shear wall in "no collapse" (severe damage) state. The maximum drift angle of the PV module is $10.75 / 1000$, and that of the shear wall is $15.06 / 1000$. The drift angle difference is about $1 / 200$ when the specimen reached the ultimate state. Therefore, the $\mathrm{U}$ shape connector plays an important role in reducing the deformation of the PV module when the shear wall has severe lateral deformation. The electricity generation efficiency also provides evidence to perfect condition of the PV module. According to Chinese seismic design of glass curtain wall [32], the drift angle limit is $3 / 1000$, while the $\mathrm{PV}$ module is not damaged when the drift angle is $10.75 / 1000$, which is far more than that of the required limit value. Therefore, even if the PV integrated shear wall structures are designed according to the current code, it meets the deformation limit requirement.

An important issue is noted here. The drift angle of shear wall is $1 / 120$ under severe earthquake in Chinese seismic design code, and the drift angle limit of glass curtain wall is $3 / 1000$ (about $1 / 333$ ), which is far less than that of shear wall. If we design the PV integrated shear wall structure with the limit of $3 / 1000$, it will be too strict for the structures and will result in much waste. Two ways are suggested to address this issue. One is to design the connector with enough deformation capacity and vibration reduction effect. The other is to amend the deformation limit of PV system. Both of the two ways need to be investigated for the seismic design.

(2) Electricity Generation Efficiency. The electricity generation variation is monitored in the same irradiation condition during the whole seismic simulation test. The collected results are divided into three stages. And the electricity generation at each stage is almost at the same condition. That indicates the electricity generation capacity is not influenced by the lateral deformation of the PV module, and the condition of the PV module is still perfect after the test.

These results indicate that, after severe earthquake hit, the PV module integrated on the buildings can be with perfect condition to continue to generate electricity, so to improve the earthquake rescue capacity by necessary power supply. That is important for life safety and earthquake relief.

(3) Thermal Performance. Under the artificial irradiation, the highest temperature of PV module reached $41.1^{\circ} \mathrm{C}$, and those of the external and internal shear wall surface tend to be maintained at $15.9^{\circ} \mathrm{C}$ and $13.7^{\circ} \mathrm{C}$. The temperature difference of the external and internal shear wall surface was maintained at $2^{\circ} \mathrm{C}$. As known to us, shear wall is a kind of structural member with good insulation performance; with external and internal insulation construction layer, the thermal performance can also be improved. So, applying the PV system to high-rise shear wall structures has both electricity generation capacity and obvious energy saving effect. The maximum temperature difference between shear wall external surface and PV module back is $28.5^{\circ} \mathrm{C}$. So, the tested temperature variation provides the evidence that the temperature increase can be obviously reduced by the existence of the air gap. The flowing air can reduce the growth of the building temperature, and, on the other hand, it can ensure that the electricity generation capacity is not influenced by the temperature increase.

(4) Construction Convenience. The construction procedure of the U-shaped steel connected PV module integrated shear wall is practiced in this experimental study. The embedded element can be fixed in shear wall conveniently. But, the bolt 
method is preferable to the weld method considering the convenience of the installation of the $U$-shaped steel connector. And the U-shaped connector needs to be optimized with the shape and dimension to install or change the PV modules. However, to allow the deformation incompatibility between the PV module and the shear wall, the optimized connector needs to have enough deformation capacity.

\section{Conclusions}

This paper proposed a U-shaped steel connected PV integrated shear wall (U-PV-SW). A lateral cyclic loading test was carried out to evaluate the seismic, electricity generation, and thermal performance. The findings and conclusions can be summarized as follows.

(1) The seismic performance of the shear wall of the UPV-SW is not obviously influenced by the integrated PV module. And the PV module is in accordance with the shear wall within the plastic drift limitation in Chinese seismic code. The U-shaped connector has obvious deformation capacity to reduce the drift angle of PV module by $1 / 200$, compared with that of the shear wall at the ultimate stage.

(2) The electricity generation capacity is not influenced by the lateral deformation of the PV module. The power output is almost the same at different deformation stages according to the shear wall seismic design limit. And, with the U-shaped flexible connection, the condition of the PV module is perfect till the completion of the test.

(3) The temperature increase can be obviously reduced by the existence of the air gap. According to the tested result, the maximum temperature difference between shear wall external surface and PV module back is $28.5^{\circ} \mathrm{C}$.

(4) The construction practice indicates the U-shaped connector needs to be further improved to meet the requirement of easy construction, optimal air gap, and the effective deformation capacity.

Applying the BIPV technology to high-rise buildings needs to meet the requirement of the seismic design code. The design code of glass curtain wall is not adequate for the design of PV module system and should be improved in future PV system design. The connector form still needs to be optimized considering the seismic safety and efficient service performance of both the PV and shear wall.

\section{Conflict of Interests}

The authors declare that there is no conflict of interests regarding the publication of this paper.

\section{Acknowledgments}

This work was financially supported by Hong Kong, Macao and Taiwan Science \& Technology Cooperation Program of
China (2012DFH70130), National Natural Science Foundation of China (51178426), Fundamental Research Funds of the Central Universities, and Zhejiang Provincial Natural Science Foundation of China (LR13E080001).

\section{References}

[1] F. Diner, "The analysis on photovoltaic electricity generation status, potential and policies of the leading countries in solar energy," Renewable and Sustainable Energy Reviews, vol. 15, no. 1, pp. 713-720, 2011.

[2] J. Peng, L. Lu, and H. Yang, "An experimental study of the thermal performance of a novel photovoltaic double-skin facade in Hong Kong," Solar Energy, vol. 97, pp. 293-304, 2013.

[3] S. Barkaszi and J. Dunlop, "Discussion of strategies for mounting photovoltaic arrays on rooftops," in Proceedings of the International Solar Energy Conference, pp. 333-338, Washington, DC, USA, 2001.

[4] S. Mekhilef, R. Saidur, and A. Safari, "A review on solar energy use in industries," Renewable and Sustainable Energy Reviews, vol. 15, no. 4, pp. 1777-1790, 2011.

[5] P. Braun and R. Rüther, "The role of grid-connected, buildingintegrated photovoltaic generation in commercial building energy and power loads in a warm and sunny climate," Energy Conversion and Management, vol. 51, no. 12, pp. 2457-2466, 2010.

[6] F. Azadian and M. A. M. Radzi, "A general approach toward building integrated photovoltaic systems and its implementation barriers: a review," Renewable and Sustainable Energy Reviews, vol. 22, pp. 527-538, 2013.

[7] D. K. Prasad and M. Snow, Designing with Solar Power: A Source Book for Building Integrated Photovoltaics (BiPV), Images Publishing, 2005.

[8] V. Delisle and M. Kummert, "A novel approach to compare building-integrated photovoltaics/thermal air collectors to sideby-side PV modules and solar thermal collectors," Solar Energy, vol. 100, pp. 50-65, 2014.

[9] M. A. Shameri, M. A. Alghoul, K. Sopian, M. F. M. Zain, and O. Elayeb, "Perspectives of double skin façade systems in buildings and energy saving," Renewable and Sustainable Energy Reviews, vol. 15, no. 3, pp. 1468-1475, 2011.

[10] National building standard design Atlas, "Building solar photovoltaic systems design and installation (10J908-5)," Beijing, China, 2010.

[11] J. Han, L. Lu, J. Peng, and H. Yang, "Performance of ventilated double-sided PV façade compared with conventional clear glass façade," Energy and Buildings, vol. 56, pp. 204-209, 2013.

[12] H. Yang, J. Burnett, and J. Ji, "Simple approach to cooling load component calculation through PV walls," Energy and Buildings, vol. 31, no. 3, pp. 285-290, 2000.

[13] J. Peng, L. Lu, H. Yang, and J. Han, "Investigation on the annual thermal performance of a photovoltaic wall mounted on a multi-layer façade," Applied Energy, vol. 112, pp. 646-656, 2013.

[14] J. J. Bloem, "Evaluation of a PV-integrated building application in a well-controlled outdoor test environment," Building and Environment, vol. 43, no. 2, pp. 205-216, 2008.

[15] L. Sun, L. Lu, and H. Yang, "Optimum design of shadingtype building-integrated photovoltaic claddings with different surface azimuth angles," Applied Energy, vol. 90, no. 1, pp. 233240, 2012. 
[16] J. Q. Peng, L. Lu, H. Yang, and J. Han, "Investigation on the annual thermal performance of a photovoltaic wall mounted on a multi-layer façade," Applied Energy, vol. 112, pp. 646-656, 2013.

[17] G. E. Lau, G. H. Yeoh, V. Timchenko, and R. K. K. Yueen, "Natural convection in a PV-integrated double-skin façade using Large-Eddy simulation," Procedia Engineering, vol. 14, pp. 3277-3284, 2011.

[18] T. T. Chow, G. Pei, L. S. Chan, Z. Lin, and K. F. Fong, "A comparative study of PV glazing performance in warm climate," Indoor and Built Environment, vol. 18, no. 1, pp. 32-40, 2009.

[19] G. Fraisse, K. Johannes, V. Trillat-Berdal, and G. Achard, "The use of a heavy internal wall with a ventilated air gap to store solar energy and improve summer comfort in timber frame houses," Energy and Buildings, vol. 38, no. 4, pp. 293-302, 2006.

[20] D. Wang, X. Guan, and S. Zhang, "Experimental study on PV solar wall," Advanced Materials Research, vol. 250-253, pp. 31343138, 2011.

[21] H.-C. Sung, S. Cheng, C. Y. Huang, and C. Chan, "An empirical study on a variety of solar panels in BIPV power conversion applications," in Proceedings of the 19th International Workshop on Active-Matrix Flatpanel Displays and Devices: TFT Technologies and FPD Materials (AM-FPD '12), pp. 297-300, Ryukoku University, Kyoto, Japan, July 2012.

[22] ASCE, "Minimum design loads for building and other structures," ASCE 7-10, New York, NY, USA, 2010.

[23] Ministry of Construction of the People's Republic of China, Code for Seismic Design of Buildings (GB 50011-2010), China Architecture \& Building Press, Beijing, China, 2010.

[24] H. Li, S. Xiao, and L. Huo, "Damage investigation and analysis of engineering structures in the Wenchuan earthquake," Journal of Building Structures, vol. 4, pp. 10-19, 2008.

[25] H. Zhang, X. Lu, and X. Wu, "Experimental study and numerical simulation of the reinforced concrete walls with different stirrup in the boundary element," Journal of Asian Architecture and Building Engineering, vol. 9, no. 2, pp. 447-454, 2010.

[26] Y. Zhou, D. Zhang, Z. Huang, and D. Li, "Deformation capacity and performance-based seismic design for reinforced concrete shear walls," Journal of Asian Architecture and Building Engineering, vol. 13, no. 1, pp. 209-215, 2014.

[27] H. Zhang, X. Lu, J. Li, and L. Liang, "Cyclic load experiment study on the laminated composite RC walls with different concrete ages," Structural Engineering and Mechanics, vol. 36, no. 6, pp. 745-758, 2010.

[28] H. M. Zhang, X. L. Lu, Y. F. Duan, and J. B. Li, "Experimental study and numerical simulation of partially prefabricated laminated composite RC walls," Advances in Structural Engineering, vol. 14, no. 5, pp. 967-979, 2011.

[29] H. M. Zhang, X. L. Lu, Y. F. Duan et al., "Experimental study on failure mechanism of RC walls with different boundary elements under vertical and lateral loads," Advances in Structural Engineering, vol. 17, no. 3, pp. 361-379, 2014.

[30] Ministry of Construction of the People's Republic of China, Code for Design of Concrete Structures (GB 50010-2010), China Architecture \& Building Press, Beijing, China, 2010.

[31] Ministry of Construction of the People's Republic of China, Code for design of steel structures (GB 50017-2003), China Planning Press, Beijing, China, 2003.

[32] Ministry of Construction of the People's Republic of China, Technical Code for Glass Curtain Wall Engineering (JGJ 1022003), China Architecture \& Building Press, Beijing, China, 2003. 

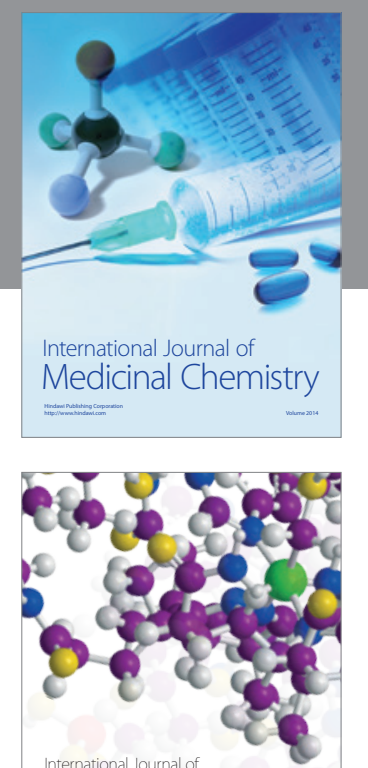

\section{Carbohydrate} Chemistry

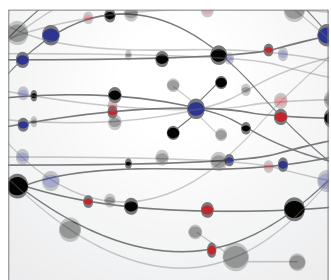

The Scientific World Journal
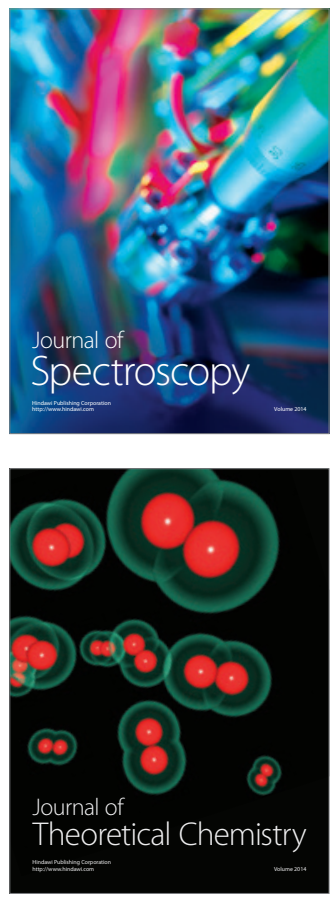
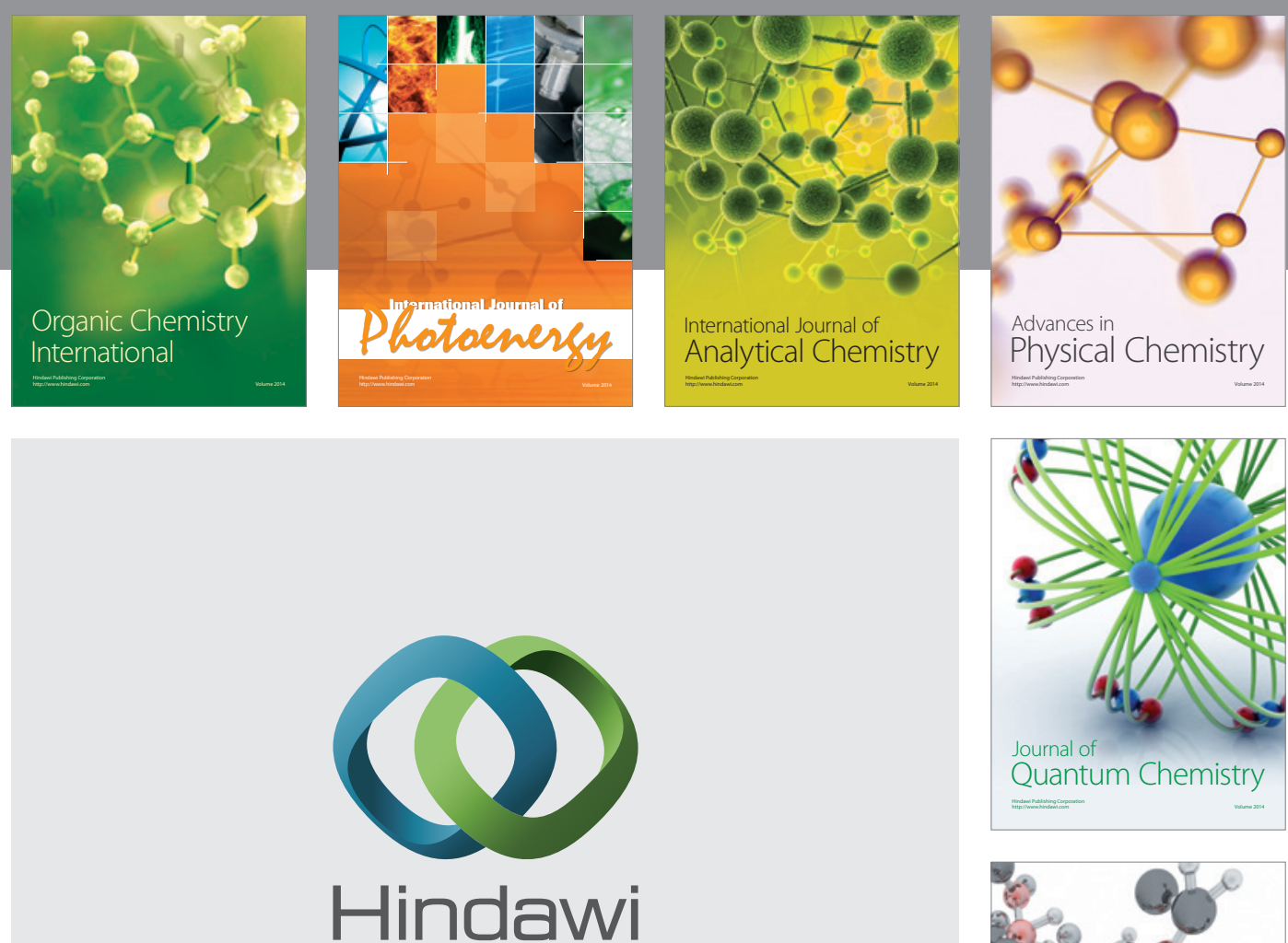

Submit your manuscripts at

http://www.hindawi.com

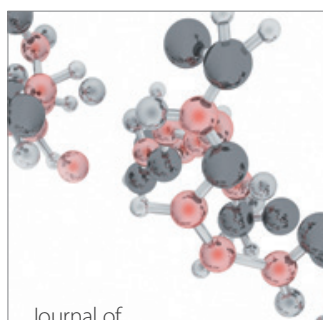

Analytical Methods

in Chemistry

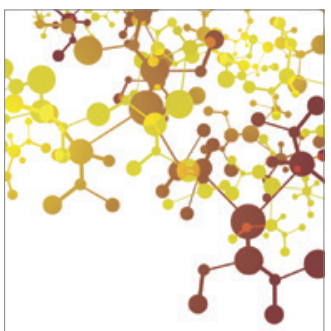

Journal of

Applied Chemistry

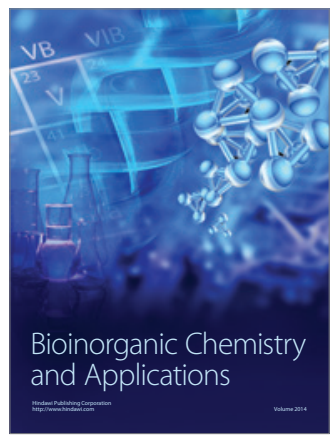

Inorganic Chemistry
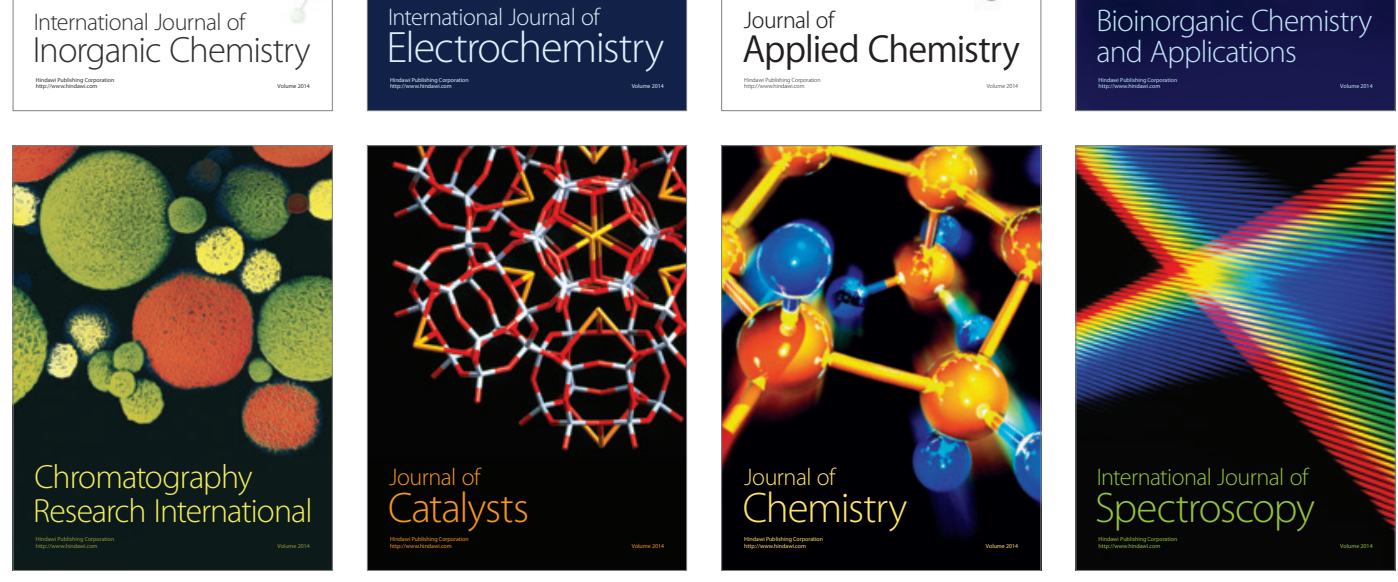